\title{
Bibliometric Studies in CIMEL: A Latin-American Medical Student Journal and the Future of Bibliometric Publications
}

\author{
Francisco J. Bonilla-Escobar, ${ }^{1}$ Johanna C. Rojas-Mírquez, ${ }^{2}$ Alvaro Mondragón-Cardona, ${ }^{3}$ Juliana Bonilla-Velez ${ }^{4}$
}

\begin{abstract}
Background: Bibliometric or scientometric studies are methodological fields focused on the structural analysis of the information contained in scientific publication and generate indicators that help identify challenges and achievements in research. We aimed to characterize the publications that used this method authored by medical students in Latin America. Methods: We reviewed articles that performed a bibliometric analysis and were published in a Latin American medical student journal, between 2001 and 2012. We analyzed the characteristics of the articles, authors and references. Linear simple regression and Pearson correlation coefficient (PCC) were developed to identify trends and correlations with $95 \%$ confidence. Results: There were 12 volumes of the journal available online, with a total of 236 articles. of these, $13(5.5 \%)$ were bibliometric studies: five original articles, four letters to the editor, two editorials, one short communication, and one review. There was a positive significant relationship between time (years) and number of publications ( $B 1=0.16, p=0.03, P C C=63 \%$ ), and citations of each article (not significant, $B_{1}=1.3, p=0.09, P C C=49 \%$ ). Conclusion: There was an increase in the number of bibliometric publications after 2008, possibly influenced by a popularization of these types of studies in Latin America. Findings should motivate new and collaborative studies in this field. Moreover, it will be necessary to clarify publication areas of interest of medical students around the world.
\end{abstract}

Keywords: Bibliometrics, Medical Students, Latin America (Source: MeSH, NLM)

\section{Introduction}

Bibliometric or scientometric studies describe, assess and monitor characteristics of publications in the scientific literature. These studies belong to a methodological field focused on the structural analysis of the information contained in scientific publications that provides different indicators that aid in the analysis of information.'

About the Author: Francisco] Bonilla-Escobar cently graduated physician and associate researcher at Cisalva Institute at the University of valle in Cali, Colombia, South America and he is Deputy Editor of the International Journal of Medical Students.
The rationale of these studies is based on the measurement of the scientific activity through established indicators of scientific publications, such as the number of published articles, the countries, institutions, research groups or individual investigators and affiliations, and the number of citations received, among others. This provides objective criteria for the critical evaluation of scientific production. Nevertheless, validity remains as a topic of active discussion due to the possible biases introduced by the same nature of its methodology. ${ }^{2}$ Some limitations are, however, inherent to these kind of studies. For instance, they may reflect an unconscious judgment from the investigator and they may not account for aspects of quality as a result of the poor and subjective evaluation of quotation and its influence in science. An additional limitation is the fact that journal indexation is limited to the most important journals, including mainly basic sciences and excluding other sources of data. ${ }^{3}$
Moreover, different areas of science have used bibliometrics, allowing for the assessment of the academic and scientific outlook of research in different regions, centers of education, and for researchers or workers on knowledge areas, among other

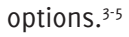

The promotion of research and scientific publication is currently a fundamental aspect of successful medical training. The Latin-American Federation of Medical Students' Scientific Societies (FELSOCEM) and its member associations (Medical Students' Scientific Societies, MSSS) have worked on promoting medical student involvement in research since its foundation in 1986. One of the main strategies to reach this goal was the establishment of their own medical students' journal, the Latin-American Students' Science and Medical Research (“Ciencia e Investigación Médica Estudiantil Latinoamericana" in Spanish, CIMEL). ${ }^{6}$

Bibliometric studies are an alternative for medical students to increase their scientific production given the relatively simple study design and the minimal resources required to plan and execute them.? This opportunity has been identified by some members of different Latin American MSSS, as it overcomes some of the difficulties and the lack of incentives that they face when attempting to do research in these countries. ${ }^{8}$ 
Figure 1. Number of Bibliometric Publications in Latin America, Published in PubMed between 1993 and 2012

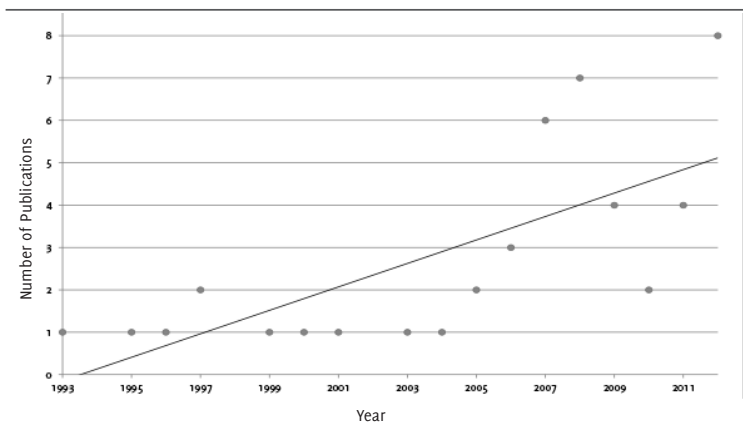

Linear fit obtained using simple linear regression $\left(B_{1}=0.3, p=0.001\right)$.

Source: PubMed database. Search strategy: "Bibliometrics"[Mesh] AND "Latin America"[Mesh] (Available from: http://www.ncbi.nlm.nih.gov/pubmed; cited 2013 August 1).

The initiative to analyze bibliometric studies published in a Latin-American medical students' journal arises from a review publication by Romani et al. where the authors discuss the method as a possible research field for medical students. ${ }^{7}$ The objective of this study is to characterize the publications that used bibliometric methods among medical students in Latin America to identify it as a publishing option for medical students and to encourage such publications among them and in the International Journal of Medical Students.

\section{Methods}

We conducted a study to identify all published manuscripts where the methodology included a bibliometric analysis of the past 12 volumes in CIMEL from 2001 to 2012. The articles were identified on the official website of the journal (Available from: http://www.cimel.felsocem.net/index.php/CIMEL/issue/archive; cited 2013 Aug 1), and the database of the Library System website of the journal's home institution, the Universidad Nacional Mayor de San Marcos [SISBIB-UNMSM] (Available from: http:// sisbib.unmsm.edu.pe/bvrevistas/cimel/anteriores.htm, updated date: Not available; cited 2013 Aug 1).

A data collection instrument was developed using the Google-Drive platform. We performed on a dataset that included variables related to the publication and their authors and then exported the data to Microsoft Excel. Variables relating to the
Figure 2. Number of Bibliometric Publications Published in CIMEL between 2001 and 2012

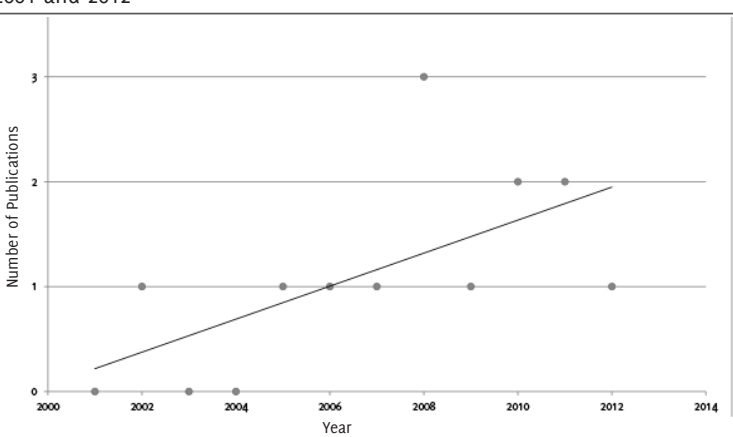

Linear fit obtained using simple linear regression $\left(B_{1}=0.16, p=0.03\right)$.

Source: CIMEL websites. (1) Library System website, Universidad Nacional Mayor de San Marcos [SISBIB-UNMSM] (Available from: http://sisbib.unmsm. edu.pe/bvrevistas/cimel/anteriores.htm, updated date: Not available, cited 2013 Aug 1st), and (2) Official CIMEL website (Available from: http://www. cimel.felsocem.net/index.php/CIMEL/issue/archive, date: Not available, cited 2013 Aug 1).

article included the type and year of publication, subject/area, funding, conflict of interest, and number of citations. Variables about the authors were authors' country of affiliation, numbers of authors as medical students and professionals, gender, highest academic degree, participation in a medical student scientific society, and institutional affiliation.

Additionally, a search in PubMed was performed using the Medical Subject Headings (MeSH) "Bibliometrics"[Mesh] AND "Latin America"[Mesh], trying to identify the trend of bibliometric studies in Latin America published in international journals.

The review and consistency of the information, the categorization of the variables, and statistical analysis were all performed in the statistical software Stata 13 (StataCorp, College Station, TX, USA). Quantitative variables are described with measures of central tendency and dispersion, while categorical variables are reported as frequencies and percentages. We used Academic Google search engine (http://scholar.google.es/) to search citations of the articles analyzed. The results were verified for each article included.

Finally, to establish the trend and relationship among the year

Table 1. Description of Published Articles by Article Type and Bibliometric Methodology in a Latin-American Medical Students' Journal between 2001 and 2011.

\section{Total Publications}

Type of Article

Original Articles

Case Reports

Editorials

Letters to the Editor

Special Articles

Short Communications

Reviews

Institutional Publications

Total

$\%$

Bibliometric Publications

(of total articles published)
$\%$

(of bibliometric publications)

$2,1 \% \quad 38 \%$

$0,0 \% \quad 0 \%$

$0,8 \% \quad 15 \%$

$1,7 \% \quad 31 \%$

$0,0 \% \quad 0 \%$

$0,4 \% \quad 8 \%$

$0,4 \% \quad 8 \%$

$0,4 \% \quad 8 \%$

$0,0 \% \quad 0 \%$

$5,5 \% \quad 100,0 \%$


of publication and number of bibliometric studies published in PubMed and number of citations of this type of study on CIMEL, a simple linear regression with $B_{1}$ coefficient and Pearson $\mathrm{CO}_{-}$ rrelation Coefficients (PCC) were calculated, respectively, with a confidence level of $95 \%$.

\section{Results}

Twelve volumes of the journal were available online: Vol. 6 to 15 were available in the SISBIB-UNMSM database and Vol. 13 to 17 were available in the official website of the journal, for a total of 236 articles published from 2001 to 2012. Of those articles, $13(5.5 \%)$ corresponded to scientometric studies. The distribution of publications by article type is described in Table 1 .

Trends in these publications in Latin America are described in Figure 1. We found 46 articles published in PubMed from 1993 to 2012 , with an increase of 0.3 publications per year $\left(B_{1}=0.3\right.$, $\mathrm{p}=0.001, \mathrm{PCC}=70.9 \%$ ) and, if the trend is analyzed for the period 2005-2008, there is an increase of 1.8 publications per year $\left(B_{1}=1.8, p=0.02, P C C=97.6 \%\right.$ ).

In CIMEL, three out of twelve $(25 \%)$ bibliometric studies were published during the year 2008; one of these articles was an original article and two were editorials. In 2010 and 2011 there were two $(17 \%)$ studies published per year while there were none published during 2001, 2003 and 2004. There is a significant upward trend of the frequency of scientometric articles ( $B 1=0.16, p=0.03, P C C=63 \%$, Figure 2 ). These studies focus mainly on journal analysis $(n=3,25 \%)$ and analysis of medical student publications in biomedical journals $(n=3,25 \%$, Table 2$)$.

These studies were performed by a total of 31 authors (median $2, p_{25}=1$ and $p_{75}=3$ ) and five of them, all from Peru, published twice (26 persons). Authors were medical students in $64.5 \%$ $(n=20)$ of all studies and medical professionals in $35.5 \%(n=11)$. Three $(12 \%)$ authors published studies during and after their medical student period. The male to female ratio for authors was 3:1 with nineteen $(73 \%)$ males and seven $(27 \%)$ females. The male to female ratio for principal authors was also 3:1 with ten $(77 \%)$ and three $(23 \%)$ articles having a male and female principal author, respectively. Most principal authors were Peruvian $(n=10,77 \%)$; other nationalities such as Venezuelan, Ecuadorian and Colombian appear in a smaller proportion $(n=1$, $8 \%$ respectively). There were collaboration groups between authors of different countries in two articles: Venezuela - Peru ( 1 , $8 \%$ ) and Peru - Spain (1,8\%).

Author affiliation to a MSSS was described in ten (77\%) articles, four $(31 \%)$ were published by the Scientific Society of San Fernando - Universidad Nacional Mayor de San Marcos (SCSF-UNMSM) in Peru and two (15\%) in the name of the Peruvian Medical Student's Scientific Society (SOCIMEP).

The highest academic degree was not described in nine (69\%) of the articles; in those described, five (19\%) were medical professionals, one ( $4 \%$ ) was a MD and MSc, and one (4\%) a $\mathrm{MD}$ and PhD. The affiliation of the medical student authors to a research group was reported in 4 articles (31\%); for medical professionals it was reported in two of five articles (40\%).

The analyzed articles do not state if they had a funding source and only one ( $4 \%$ ) out of 26 authors stated the possibility of conflict of interest because he was an editor for the journal at that time. The number of references of the articles varies by the type of publication and editorial policies of the journal, with an average of $10 \pm 6$ references (range of 4 to 23).

The average citations until 2009 were six with a range from o to 27 ; at least $25 \%$ of the articles had one citation while $75 \%$ had six citations. We found that three $(23 \%)$ scientometric studies were cited by other studies in the journal with each having one to three citations. Finally, the current study showed a trend between the year of publication and the number of citations of the article, with a tendency to increase by an average of one citation per year after the publication date $\left(B_{1}=1.3, p=0.09\right.$, $\mathrm{PCC}=49 \%$ ).

\section{Discussion}

CIMEL is an initiative created by and for medical students in Latin America to increase participation in research and promotion of scientific projects in health during medical training and continuing medical education in the region. This journal is supported by an editorial board that includes medical student members from different South and Central American countries and undergoes peer reviewed evaluation of its manuscripts.

Therefore, this approach generates a space for students to publish their research projects as principal authors, participate in the editorial process as editors, as well as to help train the next generation of medical investigators in the region. ${ }^{9}$

The current study suggests that bibliometric publications could gain more significance among scientists and medical students in Latin America, given the increasing rate of publications especially after 2008 and the correlation between the time in years and the number of publications. Romani et al. state that these kinds of studies have taken great interest for research development in Latin-American countries such as Peru due the easy access to data and the low cost and the possibility of different methodological approaches. ? This is reflected by the majority of medical student-authors being from Peru.

Studies in this area are an alternative to analyze scientific literature in different knowledge fields and scenarios. ${ }^{10}$ As a relatively simple research methodology, it offers medical students the opportunity to achieve a publication. Results from scientometric studies in Latin America tend to be more cited due to the small number of available articles in the field, leading to a positive impact on the development and consolidation of researchers." Likewise, it opens the possibility for collaborations among authors from different institutions. The combination of physical and intellectual resources is boosting the possibility of scientific publication, reflected by the country partnerships that we found in this study.

The more frequent types of publications in the analyzed journal include original articles of observational studies and case reports. Bibliometric studies were mainly consisting of original articles and letters to the editor. This situation is very similar to the trend of scientific publications, especially in low and middle income countries, where observational studies were the most common study design, reaching its highest number 
Table 2. Characteristics of Publications with Bibliometric Methodology in a Latin-American Medical Students' Journal between 2001 and 2012

\begin{tabular}{|c|c|c|c|c|c|c|c|c|c|c|c|}
\hline \multirow[t]{2}{*}{ Author, year } & \multirow[t]{2}{*}{$\begin{array}{l}\text { Countries } \\
\text { Affiliation }\end{array}$} & \multirow[t]{2}{*}{$\begin{array}{l}\text { Type of } \\
\text { Publica- } \\
\text { tion }\end{array}$} & \multirow[t]{2}{*}{ Topic/Scope } & \multirow[t]{2}{*}{$\begin{array}{l}\text { Authors } \\
\text { (n) }\end{array}$} & \multicolumn{2}{|c|}{$\begin{array}{l}\text { Medical } \\
\text { Student } \\
\text { Authors }\end{array}$} & \multicolumn{2}{|c|}{$\begin{array}{l}\text { Professio- } \\
\text { nal } \\
\text { Authors }\end{array}$} & \multirow[t]{2}{*}{$\begin{array}{l}\text { Gender } \\
\text { First } \\
\text { Author }\end{array}$} & \multirow[t]{2}{*}{$\begin{array}{l}\text { Medical } \\
\text { Student's } \\
\text { Scientific } \\
\text { Society }\end{array}$} & \multirow[t]{2}{*}{$\begin{array}{l}\text { Citations } \\
\text { (n) }\end{array}$} \\
\hline & & & & & (n) & $(\%)$ & (n) & (\%) & & & \\
\hline Avila, 2002 & Ecuador & $O A$ & $\begin{array}{l}\text { Characterization of Latin American } \\
\text { medical journals }\end{array}$ & 2 & 0 & 0 & 2 & 100 & Male & $N A^{*}$ & 3 \\
\hline $\begin{array}{l}\text { Galán-Rodas, } \\
2005\end{array}$ & Peru & $O A$ & $\begin{array}{l}\text { Characterization of medical stu- } \\
\text { dents' scientific production }\end{array}$ & 6 & 5 & 83 & 1 & 17 & Male & SOCIMEP & 27 \\
\hline $\begin{array}{l}\text { Pachajoa- Lon- } \\
\text { doño, } 2006\end{array}$ & Colombia & SC & $\begin{array}{l}\text { Medical student publications in a } \\
\text { Colombian medical journal }\end{array}$ & 1 & 1 & 100 & 0 & 0 & Male & NAV & 9 \\
\hline $\begin{array}{l}\text { Corrales- Porta- } \\
\text { les, } 2007\end{array}$ & Peru & $O A$ & $\begin{array}{l}\text { Characteristics and frequency of } \\
\text { informed consent in clinical trials }\end{array}$ & 3 & 2 & 67 & 1 & 33 & Female & $\begin{array}{l}\text { SOCIMEP, } \\
\text { SOCEMUNT }\end{array}$ & 0 \\
\hline Angulo, 2008 & $\begin{array}{l}\text { Venezue- } \\
\text { la, Peru }\end{array}$ & $\mathrm{OA}$ & $\begin{array}{l}\text { Medical student publications in } \\
\text { Venezuelan medical journals }\end{array}$ & 4 & 3 & 75 & 1 & 25 & Male & $\begin{array}{l}\text { ACUEM- } \\
\text { ULA }\end{array}$ & 5 \\
\hline $\begin{array}{l}\text { Arce- Villavicen- } \\
\text { cio, } 2008\end{array}$ & Peru & Edit & Topics of publication in the journal & 2 & 2 & 100 & 0 & 0 & Female & $\begin{array}{l}\text { SCSF-UN- } \\
\text { MSM }\end{array}$ & 6 \\
\hline $\begin{array}{l}\text { Angulo-Bazan, } \\
2008\end{array}$ & Peru & Edit & $\begin{array}{l}\text { Status of medical student journals in } \\
\text { Latin America }\end{array}$ & 1 & 1 & 100 & 0 & 0 & Female & $\begin{array}{l}\text { SCSF-UN- } \\
\text { MSM }\end{array}$ & 6 \\
\hline $\begin{array}{l}\text { Arroyo-Hernan- } \\
\text { dez, } 2009\end{array}$ & Peru & LE & $\begin{array}{l}\text { Publication of best original papers } \\
\text { selected in the International Scienti- } \\
\text { fic Congress }\end{array}$ & 1 & 1 & 100 & 0 & 0 & Male & SOCEMI & 2 \\
\hline $\begin{array}{l}\text { Montene- } \\
\text { gro-Idrogo, } 2010\end{array}$ & Peru & $O A$ & Case reports in the journal & 2 & 2 & 100 & 0 & 0 & Male & $\begin{array}{l}\text { SCSF-UN- } \\
\text { MSM }\end{array}$ & 1 \\
\hline $\begin{array}{l}\text { Montene- } \\
\text { gro-Idrogo, } 2011\end{array}$ & Peru & LE & Letters to the Editor in the journal & 1 & 1 & 100 & 0 & 0 & Male & $\begin{array}{l}\text { SCSF-UN- } \\
\text { MSM }\end{array}$ & 0 \\
\hline Romaní, 2011 & $\begin{array}{l}\text { Peru, } \\
\text { Spain }\end{array}$ & $\mathrm{R}$ & $\begin{array}{l}\text { Bibliometric studies as a research } \\
\text { area in biomedical sciences }\end{array}$ & 3 & 0 & 0 & 3 & 100 & Male & $N A^{*}$ & 2 \\
\hline $\begin{array}{l}\text { Vásquez-Sullca, } \\
2011\end{array}$ & Peru & $\mathrm{LE}$ & $\begin{array}{l}\text { Research manuscripts presented } \\
\text { at the National Medical Students } \\
\text { Meeting of Peru }\end{array}$ & 3 & 1 & 33 & 2 & 67 & Male & $\begin{array}{l}\text { ASOCIEMH } \\
\text { UNSAAC }\end{array}$ & 1 \\
\hline $\begin{array}{l}\text { Arroyo-Hernan- } \\
\text { dez, } 2012\end{array}$ & Peru & $\mathrm{LE}$ & $\begin{array}{l}\text { Anomalies about the author in me- } \\
\text { dical student's publications }\end{array}$ & 2 & 1 & 50 & 1 & 50 & Male & SOCEMI & 0 \\
\hline
\end{tabular}

*. All the authors were professionals.

Abbreviations: ACUEM-ULA: Scientific Association of Medical Students of Universidad de los Andes. ASOCIEMH UNSAAC: Medical Students Scientific Society Universidad Nacional de San Antonio Abad del Cusco. Edit: Editorial. LE: Letter to the editor. NA: Not applicable. NAV: Not available. OA: Original article. R: Review. SC: Short communication. SCSF-UNMSM: Scientific Society of San Marcos Universidad Nacional Mayor de San Marcos. SOCEMI: Medical Students Scientific Society of Ica. SOCEMUNT: Medical Students Scientific Society of Universidad Nacional de Trujillo. SOCIMEP: Scientific Society of Medical Students from Peru.

of publications during 2010 with $21.1 \%$ of published articles. ${ }^{5}$

The distribution of authors according to gender shows differences, with a high rate of males that exceeds three times the number of female authors. This is a phenomenon that has been identified in multiple areas where the numbers of female medical students and female researchers are less than males, and female research career intentions tend to decrease during medical school. ${ }^{2}$ Different movements have been established to decrease this gap, and the number of women as first and senior physician-authors has been increasing significantly but they are still a minority of the authors and members of the editorial boards of journals. ${ }^{3-15}$ Therefore, further studies are necessary to inquire about publications according to gender as well as the promotion of incentives that help to find an equitable distribution of female and male authors. ${ }^{13}$

Limitations of the current analysis include the unavailability of all issues of the Journal, as well as the absence of information regarding the institutional affiliation and academic degrees of the authors in the included studies. One of the most challenging limitations of the study is the small number of articles analyzed as the low power limits the significance of statistical tests and the ability to adjust for possible confounders. However, our findings give an idea of the importance that bibliometric studies have been acquiring in the past number of years and their impact as a novel research area with different advantages for medical students. Furthermore, it should be emphasized that these studies have some disadvantages compared to other research methodologies. ${ }^{10}$ One of the barriers of this research methodology is the inability to assess the quality of what is being published; this study is not an exception to this limitation.

Despite the reported significant increase of scientometric studies published in the journal, it remains necessary to promote 
student publication in this field in order to identify the behavior of the scientific medical student community, orientation and political efforts in research, as well as create networks that promote collaboration and new scientific activities. Thus, these publications encourage and enrich the education of students as they allow a better understanding of new perspectives and innovation in health, providing the opportunity for additional training. ${ }^{16}$

In addition, the understanding and use of bibliometric methods will address some of the difficulties presented in developing countries to do this type of research, such as the absence of experienced professors and researchers in the area and the underestimation of bibliometrics as a research field.?

Finally, scientific journals with online publications, open access, and wide dissemination provide an important scenario for publication and international visibility of studies with this approach. ${ }^{17,18}$ Therefore, it is important to increase the visibility and the quality of the articles published in CIMEL, the only regional journal for medical students in Latin-America, in order to be indexed in more visible databases such as PubMed and be able to share their investigations with a widely recognized scientific community. Bibliometric studies are needed in the International Journal of Medical Students to describe the areas of research where medical students around the world are participating in and to discuss their contributions to the scientific community.

\section{Conclusion}

Bibliometric studies are a growing area of knowledge in medical sciences and provide an opportunity for medical students to investigate and achieve publication as a result of their methods and advantages. We report that 13 of 236 articles published in 12 volumes of CIMEL were scientometric studies and there was a significant upward trend in the frequency of this type of study since 2008. These articles focused mainly on the analysis of medical student publications, and had an average of six citations with a range of 0 to 27 and a non-significant trend of one citation per year after publication date. Most authors were from Peru and there was a male to female ratio of 3:1. Studies in this area need to be done to gain insight into trends in medical students' research areas and publications and their impact in the scientific community.

\section{References}

1. Johnson MH, Cohen J, Grudzinskas G. The uses and abuses of bibliometrics. Reprod Biomed Online. 2012;24(5):485-6.

2. Sheikh L, Johnston S, Thangaratinam S, Kilby MD, Khan KS. A review of the methodological features of systematic reviews in maternal medicine. BMC Med. 2007;5:10.

3. Licea de Arenas J, Santillán Rivero EG. [Bibliometrics, why?]. Bibl Univ Nueva época. 2002;5(1):3-10. Spanish

4. Hostetter MK. What we don't see. N Engl J Med. 2012;366(14):1328-34.

5. Sifrim ZK, Barker PM, Mate KS. What gets published: the characteristics of quality improvement research articles from low- and middle-income countries. BMJ Qual Saf. 2012;21(5):423-31.

6. Niño R, Marañon R, Rodriguez A. [FELSOCEM: Scientific Vision of a Past, Present and Future]. CIMEL. 2003;8(1):61-2. Spanish

7. Romaní F, Huamaní C, González-Alcaide G. [Bibliometric studies as research line in biomedical sciences: An approach for the undergraduate degree]. CIMEL. 2011;14(1):52-62. Spanish

8. Bonilla-Escobar F], Bonilla-Vélez ], López-Castillo CA. [Medical Student Research: Perspective from Colombia]. CIMEL. 2010;15(2):94. Spanish

9. Mayta-Tristan P. [The evaluation and publication process of manuscripts in CIMEL]. CIMEL. 2003;8(1):4-5. Spanish

10. Lundberg J. Bibliometrics as a research assessment tool: impact beyond the impact factor. Stockholm, Sweden: Karolinska Institutet; 2006.

11. Stidham RW, Sauder K, Higgins PD. Using bibliometrics to advance your academic career. Gastroenterology. 2012;143(3):520-3.

12. Guelich JM, Singer BH, Castro MC, Rosenberg LE. A gender gap in the next generation of physician-scientists: medical student interest and participation in research. J Investig Med. 2002;50(6):412-8.

13. Mansour AM, Shields CL, Maalouf FC, Massoud VA, Jurdy L, Mathysen DG, et al. Five-decade profile of women in leadership positions at ophthalmic publications. Arch Ophthalmol. 2012;130(11):1441-6.

14. European Technology Assessment Network Expert Working Group on Women and Science. [Science Policies in the European Union: promoting excellence though mainstreaming gender equality]. Bruselas, Belgica: European Commision; 2000

15. Jagsi R, Guancial EA, Worobey CC, Henault LE, Chang Y, Starr R, et al. The "gender gap" in authorship of academic medical literature--a 35-year perspective. N Engl J Med. 2006;355(3):281-7.

16. Fischer MR. Undergraduate Medical Education as a Foundation for Health Care and Research. Dtsch Arztebl Int. 2012;109(18):325-6.

17. Boulton G. Open your minds and share your results. Nature. 2012;486(7404):441.

18. Nair V, Khan S, Jhaveri KD. Interactive journals and the future of medical publications. Am J Med. 2012;125(10):1038-42.

\section{Acknowledgments}

None.

Conflict of Interest Statement ct Funding

The Authors have no funding, financial relationships or conflicts of interest to disclose.

Cite as:

Bonilla-Escobar FJ, Rojas-Mírquez JC, Mondragón-Cardona A, Bonilla-Velez J. Bibliometric Studies in CIMEL: A Latin-American Medical Student Journal and the Future of Bibliometric Publications. Int J Med Students. 2013;1(3):115-9. 